Issledovatel'skiy Zhurnal Russkogo Yazyka i Literatury, Vol. 9, Issue 2, 2021, Pp: 53-73

DOI: 10.52547/iarll.18.53 DOR: 20.1001.1.23452498.2021.9.2.3.1

Article No.: 18.32.20212.5373

Scientific Article

\title{
Apocalyptic Images and Their Variations in N. S. Gumilyov's Poetry
}

\section{Koshemchuk Tatiana Alexandrovna ${ }^{1 *}$}

Professor of Saint-Petersburg Agrarian University,

St. Petersburg, Russia.

\section{Bondarev Aleksey Vladimirovich ${ }^{2}$}

Associate professor of the Department of theory and history of culture of Herzen

State Pedagogical University,

St. Petersburg, Russia.

(date of receiving: May, 2021; date of acceptance: June, 2021)

\begin{abstract}
The article analyzes the use of apocalyptic images in the poetry of N.S. Gumilyov. Symbolic imagery is generally understood in the context of its Patristic interpretation, as well as from the perspective of R. Steiner's Anthroposophy. It is shown that Gumilyov's worldview, manifested in his poems, is colored eschatological and reflects the world as a whole from the days of Creation on the day of the Last Judgment. The things of the world that attract the poet are evaluated in their correlation with the end of the world, whether it is wanderings, love, Russia, death. Apocalyptic images in Gumilyov's poetry appear in their various transformations: an exact mention, a hint, a variation in the poet's imagination, or the development of an image in the spirit of the original. At the same time, the images are used according to the spirit of the Apocalypse and it reflects the depth and originality of the poet's worldview.
\end{abstract}

Keywords: N. S. Gumilyov's Poetry, Symbolic Images, Apocalypse, Interpretations of the Patristic Authors, R. Steiner's Anthroposophy, Great-Memory, Wanderings.

1. E-mail: koshemchukt@mail.ru * Corresponding author

2. E-mail: aleksej-bondarev@yandex.ru 


\title{
Апокалипсические образы и их вариации в поэзии Н.С. Гумилева
}

\author{
Кошемчук Татьяна Александровна ${ }^{1 \text { * }}$ \\ Профессор Санкт-Петербургского аграрного университета, \\ Санкт-Петербург, Россия.
}

\section{Бондарев Алексей Владимирович²}

Доцент кафедры теории и истории культуры Российского государственного педагогического университета им. А.И. Герцена,

Санкт-Петербург, Россия.

(дата получения: май 2021 г.; дата принятия: июнь 2021 г.)

\begin{abstract}
Аннотация
В публикуемой статье анализируется использование апокалипсических образов в поэзии Н.С. Гумилева. Символическая образность понимается в контексте ее святоотеческой интерпретации, а также с позиции антропософии Р. Штейнера. Показывается, что мировоззрение Гумилева, проявленное в его стихах, окрашено эсхатологически и отражает мир в его целом от дней Творения до дня Суда, а привлекающие поэта сущности бытия оцениваются в их соотнесенности с концом мира, будь то странствия, любовь, Россия, смерть. Апокалипсические образы в поэзии Гумилева предстают в их различных трансформациях: точное упоминание, реминисценция, варьирование в фантазии поэта или развитие образа в духе первоисточника. При этом бытование образа всякий раз выдержано в духе Апокалипсиса и тем самым отражает глубину и самобытность религиозного мировоззрения поэта.
\end{abstract}

Ключевые слова: Поэзия Н.С. Гумилева, Символические Образы, Апокалипсис, Толкования Отцов Церкви, Антропософия Р. Штейнера, Прапамять, Странствие.

1. E-mail: koshemchukt@mail.ru * Ответственный автор

2. E-mail: aleksej-bondarev@yandex.ru 


\begin{abstract}
Введение
Апокалипсис - великая книга о конце мира, образы которой стали предметом для многовековых усилий в толковании внутри различных религиозных традиций, а также и для мыслителей светских, которых притягивает неведомая рациональному сознанию глубина ее сообщений о неизбежности конца земной истории. Апокалипсис становился значительным источником образности для тех поэтов, которые в своих историософских размышлениях настроены на эсхатологический лад. Образы его дают поэту неисчерпаемые возможности в создании оттенков собственной мысли, в выявлении своеобразия авторского «Я». Бытование образа в поэтическом тексте всякий раз особенно: от прямой его трансляции до эмоционального и ассоциативного намека. Весь спектр форм мы найдем в стихотворениях Н.С. Гумилева, в поэтическом сознании которого апокалипсические образы были чрезвычайно действенны, входя в общий широкий историософский фон его мысли. Они, однако, не привлекали специального внимания исследователей, но лишь упоминались в связи с христианскими образами у русских поэтов в целом или же при описании отдельного образа в русской поэзии (как, например, образа кометы). Анализ их смысловой нагрузки и особенностей их трансформации в поэзии Гумилева предпринимается впервые.
\end{abstract}

\title{
Основная часть
}

Вообще религиозные образы в первоисточниках различных традиций являются их значимой частью. Так, святоотеческие авторы, говоря о Боге, постоянно использовали богатейший образный арсенал, ибо духовные познания и мистические откровения, выражаемые на обычном языке, не пригодном для мира духа, но ориентированном на мир материальный, становятся лишь бледными тенями пережитого. Символические же образы в 
этой ситуации дают намеки на невыразимое, что было осмыслено впервые св. Дионисием Ареопагитом: «...невозможно, чтобы богоначальный луч воссиял нам иначе, нежели возводительно окутанный пестротой священных завес» (Дионисий Ареопагит 2002. 41). Священные завесы и есть земные образы для высших истин. Образы-завесы призваны выражать мысль так, чтобы одновременно скрыть ее от незнающих и недостойных, а достойных возводить от внешнего - к внутреннему. По св. Дионисию, «невозможно уму нашему возвыситься до невещественного подобия небесных иерархий и их созерцания, если он не воспользуется соответствующим ему вещественным руководством...» (Дионисий Ареопагит 2002. 43). Здесь св. Дионисий говорит о небесных иерархиях, но эти предупреждения всецело относятся и к апокалиптическим сообщениям, данным именно через образную пеструю завесу - то есть возводящим к тому сущностному, что «дано небесным существам надмирно, а нам образно (символически)» (Дионисий Ареопагит 2002. 43). Св. Максим Исповедник, его толкователь, дает важное для нашего понимания подобных священных текстов разъяснение: ничто в них «не названо как придется, но все - с большим знанием и подлинно с благочестием» (Максим Исповедник 2002. 45). Сам св. Дионисий говорит, что божественное «выявляется и неподобающими ему символами» (Дионисий Ареопагит 2002. 47), перечисляя те многоликие образы существ, которые нам нужно понимать правильно, не воображая материальные вещи, как «некие огненные колеса над небом» или «материальные престолы» для восседания, называет и львов, быков, птиц и «неких разномастных коней» (Зах. 1:8), наряду со всем прочим - с пестротой разномастных символов (Дионисий Ареопагит 2002. 47). «Богословие ведь решительно воспользовалось поэтическими священноизмышлениями применительно к не имеющим образов умам, изучив, как сказано, наш ум, предусмотрев свойственную и прирожденную ему способность возведения и создав для него возводительные 
священоописания» (Там же. 47-49). «Небесные символы, - поясняет св. Максим, - сходствуют с фантазиями поэтов» (Максим Исповедник 2002. 47).

Возводящие образы эти двояки: подобные (такие Имена Божьи, как Слово, Ум, Сущность и отрицательные определения, как несозданность, невидимость и т.д.) и неподобные; вторые - до полной инаковости, как например, трубы или кони Апокалипсиса. Образность, и особенно образы неподобные, неотъемлемая черта стиля святоотеческих творений, так что само определение образа содержит в себе образ: как тело есть завеса для души, так как образ есть завеса для сокровенного, и то и другое есть и откровение смысла, и сокрытие его. «Мы видим в тварях образы, показывающие нам тускло божественные откровения, когда, например, говорят, что Святая безначальная Троица изображается через солнце, свет и луч; или через бьющий ключом источник, текущий поток и русло; или через ум, слово и дух...» (Дамаскин 1913. 400). Мысль о необходимости подобий мы находим и у свт. Григория Паламы - об Апокалипсисе он замечает, что автор его учит нас о конце света, учит нас снисходя к нашей возможности разумения, посему и вводятся «молнии», «облака», «трубные звуки», «престолы» (Палама 1993. 46). Эти образы лишь отчасти раскрываются современному человеку, по мере его погруженности в традицию, но вряд ли возможно исследователю постичь их, не владея тем же духопознанием, что было открыто творцам традиции, так что в итоге и неизбежно образы Апокалипсиса в сумме всех толкований все же остаются для нас загадочными.

Можно подойти к образам Апокалипсиса и с позиции данной в начале 20 века антропософии Рудольфа Штейнера: они говорят на языке древних мистерий, которые играли огромную роль мировых центров, обладающих тайным для всех остальных знанием, импульсируя развитие культуры через великих учителей. Ближе всего к нам египетские и древние греческие мистерии, следы которых дошли и в произведениях культуры, которые может 
ощутить любой и внешний исследователь. Но большего понимания достигает тот, кто стремится в своем познании к некому порогу тайны, за который переходили лишь жрецы, посвятившие себя служению в сокровенных культах. В определенный момент истории - в момент пришествия Христа, импульсы древних мистерий были исчерпаны и сохранялись далее лишь в слабых отпечатках культуры. Так Штейнер указывает на необходимость понимания того языка, на котором был написан Апокалипсис; он также истолковывает в своих сообщениях и отдельные апокалипсические образы, относя их к различным эпохам в развитии человеческого сознания. В частности, он говорит о нашем времени, как о европейской культурной эпохе, когда в центре развития человека - самосознающая душа, и она связана со снятием четвертой печати и явлением бледного коня и Всадника, имя которого - Смерть (Откр. 6:8): «смерть действительно вступает в человечество» (Штейнер 2009. 90) - и мы все еще не преодолели отжившее свой век сознание, в центре которого смерть: человек живет лишь между рождением и смертью, как если бы в этом заключалась вся его жизнь, и лишь немногие люди в нашу эпоху несут в себе сознание, которое «не останавливается на жизни между рождением и смертью» (Штейнер 2009. 93), но осознают себя в истории мироздания, живущими в вечности до рождения и после смерти. К таким людям обращается автор Апокалипсиса, «он стремился именно к тому, чтобы Апокалипсис был прочитан лишь теми, кто к этому призван» (Штейнер 2009. 316). И об истории мира, в центре которой - Христос, он говорил на языке имагинативных видений, почерпнутом из древних мистериальных учений.

Воздействие этого мистериального языка огромно. Николай Гумилев описывает в прозаическом произведении «Вверх по Нилу» (1907 г.), как во время странствий по Египту он попал в глубь пирамиды, которую почувствовал в приливе древней памяти, как «старую, старую и странно родную» (Гумилев 2000. 57). Он в этом странном мире пережил пробуждение 
древней памяти - и проникновение в древний язык образов, который закрыт для рассудочного сознания. С ним произошло нечто потрясающее: на стене пирамиды был написан некий древний текст, на очень старом египетском языке, виденном лишь в Британском музее, и вдруг он в особом состоянии сознания неожиданно читает этот древний текст, понимает его, и воздействие его было огромно, родственно его душе, могущественно: «Это были слова, полные сладким пьяным огнем, которые ложились на душу и преображали ее, давая новые взоры, способные понять все» (Там же. 58) - и при таком проникновении в сокровенное не только душа поэта прозревает, но и мир в целом может перемениться: «одно слово... и новое солнце запляшет в золотистой лазури...» (Там же.). Это поразительное переживание, описанное Гумилевым, приоткрывает его духовный мир, который был охарактеризован Ю.В. Зобниным как имеющий «"мистическое", "эзотерическое" основание» (Зобнин, 2000. 19). Поэт был истинным странником не только по земле, но и по духовным мирам разных традиций, и по культурам, западным и восточным. Его глубокое, врожденное православное мировоззрение было таково, что глубины иных религий были ему понятны и притягательны, он стремился постичь весь духовный опыт, обретенный человеком на различных путях.

Так, мистические аспекты восточных традиций влекли его чрезвычайно, и он, паломник в миры востока, долго живет в Каире, устремляясь к некой таинственной стране из своих сновидений - так он описывает это в раннем своеобразном травелоге «Вверх по Нилу». Но память не удерживает эти сны, а внешние знаки восточных культур не властны над его душой, их символами выступают красные шелковые занавески и персидский ковер. Целью же глубинных стремлений является та страна, что находится в центре Африки, в тропических лесах, где, по словам нищего дервиша, живут потомки царяволхва Балтазара. Об этом говорит главному герою, выразителю авторской точки зрения, его случайный знакомый, англичанин, который также влеком 
древним знанием - и стремится, как он выражается, к «новому познанью, которое укажет другую сторону всех вещей» (Гумилев 2000. 57). Мистер Тьери - так назван этот герой - продолжает: «...найдите его, и вы будете изумлены, как Вы могли считать облако атмосферическим явлением, когда оно на самом деле звездокрылая бабочка...» (Там же.). Слова о новом познанье стали ключевыми, и главный герой, названный мистером Грантом, немедленно реагирует: «Если Вы позволите, мистер Тьери, я поеду с Вами» (Там же.). И вот двое странников едут по Нилу и во время остановки входят в маленькую пирамиду. Главный герой спускается с факелом в руках в яму, открывшуюся после оборвавшейся лестницы и оказывается в этом страннородном мире, где его встретили обитатели пещеры - змея и жаба, которые никогда не видели света.

Отметим далее характерную черту гумилевской поэзии: здесь, как и в ряде иных текстов, автором выражается чувство сродственности с тем или иным феноменом как намек на знакомство с ним в прежнем воплощении его души. Подобные всплески прапамяти, данные в чувстве близости к неведомому ранее миру, есть верная гарантия понимания того мира, в который привело его странствие. Это переживание сопровождается и еще одним неясным чувством: грустью без всякого оснований: «...так грустно как никогда еще не бывало» (Там же.). Итак, герой читает на стене пещеры древний текст... Здесь и происходит неожиданное: «должно быть благословение задумчивой жабы просветило мой ум...» (Там же. 58), - пишет Гумилев, смягчая легкой иронией дальнейшее невероятное переживание: чтение «мильх, мильх святых букв» и огненных слов. «Я плакал слезами благодарности и чувствовал, что теперь мир переменится... и новое солнце запляшет в золотистой лазури и все ошибки превратятся в цветы» (Там же.). Затухающий факел не дал дочитать, а на поверхности его ждала... острая вспышка нильской лихорадки и три недели болезни. Так автор мотивирует случившееся с ним, мягко отсылая к 
приемлемому для разума, но понятая мистером Тьери тайна пережитого была сигнализирована в его словах: «Бойтесь задумчивых жаб».

Гумилев говорит в этом отрывке о мощном воздействии древнего мистериального языка - пирамиды были именно центрами древних египетских мистерий и хранительницами тайного знания - и лишь слабые отголоски этого языка несет в себе поэзия. В частности, и поэзия самого Николая Гумилева. А мотив пробуждения памяти стал одним из повторяющихся в его лирике, отражая некую сущностную черту сознания поэта. «Прапамять» - таково название одного стихотворения; в нем даны потоки видений, встающих из памяти о прежних жизнях, о «потерянном навсегда», и вперемешку отголоски настоящего:

Бушует пламя, трубят трубы,

И кони рыжие летят,

Потом волнующие губы

О счастье, кажется, твердят.

Вся жизнь, постигаемая странником, «моря, пустыни, города», предстает как «отраженье» «потерянного навсегда», когда-то своего, и в цепочке жизней в прапамяти поэта восстают иные страны, и самая ранняя - Индия, так что в итоге стихотворения он думает о том миге в будущем, когда он снова найдет себя там, как когда-то:

Когда же, наконец, восставши

От сна, я буду снова я, -

Простой индиец, задремавший

В священный вечер у ручья?

Мир этого стихотворения - мир Апокалипсиса, в нем «бушует пламя, трубят трубы, / И кони рыжие летят...». И ангельские трубы, и рыжие красные кони, несущие Всадников, имя которым - война, говорят о бедствиях 
человечества в эпоху, когда поэт-странник среди пустьнь u городов, проживает свое последнее воплощение - и ждет итогового возвращения к первой из ряда вставших в его прапамяти жизней.

И те же устрашающие ангельские трубы Апокалипсиса являются вдруг и в стихотворении Гумилева о любви («О тебе») - в обращении поэта к Богу и в прошении к Нему дать «ослепительный ответ» на вопросы его возлюбленной:

Ведь отрадней пения птиц,

Благодатней ангельских труб

Нам дрожанье милых ресниц

И улыбка любимых губ.

В этом финале стихотворения утверждается повторяющаяся тема поэта, обретающая всякий раз пронзительные слова о том, что высшая в мироздании ценность - это разделенная любовь. И в этой возвышенной теме апокалипсический образ ангельских труб, сулящих в первоисточнике должные, назначенные испытания и бедствия, у поэта становится «благодатным» знамением, ибо он приходит свыше. И тем самым можно отметить: апокалипсические образы живут в душе поэта как постоянный фон для переживаний, как естественный источник образных средств при воплощении его мыслей о важных для него аспектах бытия. Так «ангельские трубы» являются в мысли поэта, когда он поет гимн той, кого любит: «ты»по мысли поэта, «призыв к вышине» в его судьбе; «твое» «благородное сердце», - освещение всего бытия в целом; «твои» глаза - звезды для всей нашей земли; наконец, в концепции стихотворения, мысль о последних временах вновь приходит к поэту:

И когда золотой серафим

Протрубит, что исполнился срок, 


\begin{abstract}
Мы поднимем тогда перед ним,
Как защиту, твой белый платок.

Звук замрет в задрожавшей трубе,

Серафим пропадет в вышине...
\end{abstract}

Так разворачивается в фантазии поэта тема Апокалипсиса в гиперболах стихотворения: «ты» есть защита и от конечного призывного ангельского гласа к суду, «твоя» чистота (белизна твоего платка) защитит, даже отдвинет последний час - и это страстное признание величия несравненной души возлюбленной завершается повтором начального: «...О тебе, о тебе, о тебе, / Ничего, ничего обо мне!».

Органичны такие употребления образов Откровения для поэта, в круг мыслей которого постоянно входит Библия как неотъемлемая составляющая всей его жизни. Об этом здесь, в рамках этой статьи, скажем лишь попутно, в двух примерах из целого ряда. Так, думая об Африке, он выделяет ее связь со Священной историей - и с личной судьбой:

\title{
Дай скончаться под той сикоморою, \\ Где с Христом отдыхала Мария.
}

А в стихотворении о Красном море непременным фоном и финалом его становится воспоминание о Моисее - и это священное событие столь же непосредственно связано с жизнью поэта: это единственное море исполнило когда-то Божий закон:

Разорвало могучие сплавы зыбей,

Чтоб прошел Моисей и погиб фараон.

Прежде всего, именно странствия по миру нуждаются в подобном контексте у Гумилева. Не раз было отмечено и теперь уже очевидно для 
исследователей, что странствие - сквозной и центральный образ его поэзии (см.: Зобнин, 2000), и это прочно сближает его по духовному типу с символистами второй волны. Гумилевский странник, конечно, обладает особенными чертами: подчас он торжествующий победитель и завоеватель, когда речь идет о внешнем, подчас - печальный, хмурый и бесконечно скорбный («Странник»), когда раскрываются глубинные мотивы его странствия: он не может не стремиться все далее, в просторах мира изживая свое вечное стремление, странник, который «...снова должен ехать, должен видеть / Моря, и тучи, и чужие лица...» («Эзбекие»). Ибо он и духовный странник по мирам культур и религий, который истинно проживает эти миры, приобщившись к ним в живом прикосновении. При этом он может мыслить мир не иначе, как развертывающимся в огромных земных просторах от дней Творенья и до дня Суда, то есть во всем вселенском размахе. Об этом говорит изумительное гностическое стихотворение Гумилева 1919 года «Душа и тело», в котором в действительности три героя (не два - душа и тело), ибо репликам души, воплощенной в теле и все еще помнящей о хоре планет из преджизни (о былом, «мерцающем в планетном хоре») и тела, не знающего бытия («Не знаю я, что значит бытие...»), отвечает, завершая стихотворение, третий голос голос духа, «Я», к которому с вопрошанием «Кто ты?» обращены и душа, и тело:

Ужели вам допрашивать меня,

Меня, кому единое мгновенье

Весь срок от первого земного дня

До огненного светопреставленья?

Волошинскому «человеческий дух древнее, чем земля и звезды» (Волошин 1977. 378) Гумилев здесь словно отвечает, подтверждая: для человеческого духа «...как пыль, / Поля земные и поля блаженства». «Я» человека выше 
всего в Творении, и оно, его имя («прозванье») еще скрыто от самого человека: «Я тот, кто спит, и кроет глубина / Его невыразимое прозванье...». Это духовное «Я», несомое душой поэта, осознается как высшее задание и главная цель мира от его сотворения и до конца - до «светопреставленья». Мы находим в стихах поэта верные отпечатки подобного самосознания, обещающего в будущем огромные духовные и творческие плоды. Увы, путь поэта был трагически оборван, и его мировоззренческая концепция осталась невыраженной. Но, прослеживая в стихах симптомы величественного космического мирочувствия, можно отметить глубинную причастность поэта к каждой сущности мира, в которой он опознает то, что было прежде пережито, и душа поэта глубже всего погружается, всем существом, в те вехи странствий, которые были отмечены когда-то в иных жизнях. Скажем в итоге: в своих странствиях поэт переживает прежде всего глубокую и отдающую печалью и тоской приобщенность к прошедшим страницам мира - и истории своего «Я». Именно этим чувством влеком гумилевский странник по миру страстью познания мира как себя и себя как мира.

В прежние, когда-то знакомые области мира постоянно стремится он, поэтому и «нужно» ему странствовать, следуя сновидческому переживанию: «И мне снилось ночью: плыву я / По какой-то большой реке...» И если в своей обычной жизни сердце «смертно тоскует», то его страннические пути светлы («Мадакаскар»):

\footnotetext{
С каждым мигом все шире, шире

И светлей, и светлей река

Я в совсем неведомом мире,

И ладья моя так легка.
}

Отголосок когда-то в иной жизни пережитого поэт ощущает ярче всего на юге, в Африке, но также и в Европе, в Италии (об этом говорит цикл 
итальянских стихотворений), и на севере, в «зеленой и солнечной» Скандинавии («Стокгольм»), чувствуя и в ней некую былую родину, с ее утраченными «родимыми реками»:

И понял, что я заблудился навеки

В слепых переходах пространств и времен,

А где-то струятся родимые реки,

К которым мне путь навсегда запрещен.

Так круг прежних жизней странника и его теперешних географических притяжений весьма обширен, как во времени, так и в пространстве, и воспоминания о прошлом настигают его в разных точках мира. При этом в странствиях его есть некая незыблемая точка. Странник обретает истинную отраду в своей связи с родиной, в мыслях о России. И характерно, что эти мысли также распахнуты в апокалипсическое измерение, он думает не об историческом благополучии для страны, но о ее эсхатологической значимости:

Сердце бьется пламенем палимо

Вплоть до дня, когда взойдут, ясны,

Стены Нового Иерусалима

На полях моей родной страны.

И тогда повеет ветер странный

И прольется с неба страшный свет,

Это Млечный Путь расцвел нежданно

Садом ослепительных планет.

Венцом этой фантазии о России как об идеальном апокалипсическом Граде будущего становится Тот, Чей приход обещает Апокалипсис, Кого сопровождают в видении поэта апокалипсические звери: 
Предо мной предстанет мне неведом,

Путник, скрыв лицо, но все пойму,

Видя льва, стремящегося следом,

И орла, летящего к Нему.

Можно обобщить: каждое прекрасное явление мира у поэта словно эсхатологически взвешивается, измеряется мыслью об устремленности мира к концу. Так, России оказывается посильно стать Новым Иерусалимом для всего мира. То же взвешивание выдерживает и еще одна великая земная область - пустыня Сахара, соизмеримая с русским пространством. Громадность и вечность своевольных движущихся песков Сахары, их мощь «до скончанья веков» говорят поэту в еще одной его фантазии о конце современного мира - о поглощении всей Европы пылающими «хищными стаями песков» Сахары, о возвращении мира к первобытности, опять же туда, откуда и начинала свои пути душа поэта, на все будущие жизни очарованная священной простотой первобытного начала:

Средиземное море засыпят они,

И Париж, и Москву, и Афины,

И мы будем в небесные верить огни,

На верблюдах своих бедуины.

И когда, наконец, корабли марсиан

У земного окажутся шара

То увидят сплошной, золотой океан

И дадут ему имя: Сахара.

Наряду с подобными произвольными образами, поэт и иначе выражает свое эсхаталогическое чувство - как распахнутость мира и своей судьбы к конечному этапу, к Апокалипсису и к итоговому Суду. К нему сам поэт, лично, готов, как говорит его стихотворение последнего года жизни («Мои 
читатели»), и он может научить главному - этой готовности и своих читателей:

... представ перед ликом Бога

С простыми и мудрыми словами,

Ждать спокойно Его Суда.

Тема собственной смерти и Суда в стихах поэта оркеструется и образами апокалиписических всадников. И, что характерно, у Гумилева в стихах не востребован (как у других поэтов-современников) четвертый Всадник на бледном коне, впрямую связанный со страхом смерти, с подчиненностью смерти современного человека, в прямом соответствии с апокалипсическим именем всадника «Смерть». Гумилев в стихотворении «Смерть» говорит о достойной смерти в бою - и в центре его образ белых апокалипсических всадников. Лишь под пулями «веришь в знамя Господне», - говорит поэт, а далее в стихотворении: веришь, что когда «милый день уплывет из глаз», то в двух центральных строфах - душе откроется то, что в Апокалипсисе, сокрытое ранее:
Свод небесный будет раздвинут
Пред душою и душу ту
Белоснежные кони ринут
В ослепительную высоту.
Там Начальник в ярком доспехе,
В грозном шлеме звездных лучей
И к старинной, бранной потехе
Огнекрылых зов трубачей.

Так в предвкушаемом посмертном видении душа воина, павшего в бою, будет вознесена ввысь белыми конями чистоты и святости, теми конями, 
которые в Апокалипсисе (в 19 главе) упомянуты как несущие Белого Всадника и Его воинство:

11. И увидел я отверстое небо, и вот конь белый, и сидящий на нем называется Верный и Истинный, Который праведно судит и воинствует. $<\ldots>$

14. И воинства небесные следовали за Ним на конях белых, облеченные в виссон белый и чистый.

(Откр. 19:11-14)

Представший в видении поэта Христос есть апокалипсический Воитель в доспехах, в грозном Своем лике, а ангельские трубы звучат как бранные призывы. Так в полном соответствии с апокалипсическим духом рисуются поэтом картины посмертия.

Подобными же чертами был описан в Библии и явившийся в храм Бог (во второй книге Маккавеев) на коне белом как золотой страшный Всадник, чтобы остановить святотатство и изгнать язычника Илиодора, вознамерившегося ограбить казну Иудейского храма, но он был поражен страхом и ужасом,

...ибо явился им конь со страшным всадником, покрытый прекрасным покровом: быстро несясь, он поразил Илиодора передними копытами, а сидевший на нем, казалось, имел золотое всеоружие.

(2 Мак. 3:25)

Эти неподобные образы Всадников изображают самого Бога или Его посланников, и именно с ними связан еще один великолепный образ у Гумилева - в легенде «Золотой рыцарь», описывающей смерть рыцарейкрестоносцев в пустыне Святой Земли и их предсмертные видения. Умирающим от жажды рыцарям явился Золотой рыцарь на коне «золотистой масти», который «дыбился и прыгал и еле касался копытами гулких утесов» 
(Гумилев 2000. 126), а на нем Всадник в золотых доспехах с лицом «совершеннейшей красоты, которая когда-нибудь цвела на земле и на небе» (Там же. 127), с глазами, «полными светлой любовью» (Там же.), и Он, сразившись с ними, потом с ними «и ел и пил, и смеялся» (Там же. 128), напоминая о воскресшем Христе в Евангелии, и проводил их по белой лестнице, ведущей в небо.

\section{Заключение}

Bce апокалипсические темы и образы у поэта, все строки, процитированные здесь, за исключением легенды о Золотом Рыцаре, являются лишь фрагментами стихотворений, не центральными темами, но попутными, и мысль Гумилева в их контексте, обозначив то, что здесь приведено и акцентировано, чаще всего далее возвращается к земному, например, к земной красоте смерти в бою или к земной любви, к центральному «полному счастью» жизни, к любви разделенной. Нужно отметить в итоге и симптомы не достигнутой поэтом совершенной выраженности его мировоззренческой концепции: порой это произвольность эсхатологических фантазий, порой затемненность мысли, как напрмер, в воссоздании отголосков прежних жизней, также незрелость отдельных мотивов, особенно стремления к возврату в первобытную простоту древних исторических этапов - в духе вечного возвращения, этой модной ницшеанской идеи гумилевского времени. Тем не менее апокалипсическая образность, естественно звучащая в средоточии ряда важнейших тем поэта, проходящая одной из тонких и ярких нитей в его творчестве, варьируемая и представленная в разных своих гранях, то как очевидная отсылка к священному тексту, то как явный намек, то как произвольная фантазия на тему конца мира, или как тонкое развитие апокалипсического образа с сохранением духа первоисточника - все это можно воспринять лишь как подступы к главной, впереди еще ждущей поэта 
центральной его духовной теме: Человека как центра истории, Истории как становления его сознания, как арены, на которой разыгрываются земные события, направляющие мир от дней Творенья до дня Суда. Незавершенность темы, точнее, лишь первые ее проявления в творчестве, обещающие близкий расцвет, еще раз говорит нам о том, что ранняя трагическая смерть поэта застала его на пороге его творческой и духовной зрелости, не сбывшейся в его земной судьбе.

\section{Литература}

1. Волошин М.А. (1977). Стихотворения. Л.: Советский писатель, 464 с.

2. Дамаскин И., св. (1913). Три защитительных слова против пориающих святые иконы или изображения // Полное собрание творений св. Иоанна Дамаскина. СПб., т. 1. 442 с.

3. Дионисий Ареопагит (2002). О небесной иерархии // Дионисий Ареопагит. Сочинения. Максим Исповедник. Толкования. СПб.: Алетейа, 864 с.

4. Зобнин Ю.В. (2000). Странник духа // Н.С. Гумилев: pro et contra. Личность и творчество Николая Гумилева в оценке русских мыслителей и исследователей. Антология. Санкт-Петербург, Изд-во РХГА, с. 6-52.

5. Максим Исповедник (2002). Толкования // Дионисий Ареопагит. Сочинения. Максим Исповедник. Толкования. СПб.: Алетейа, 864 с.

6. Н.С. Гумилев: pro et contra. Личность и творчество Николая Гумилева в оценке русских мыслителей и исследователей. Антология. (2000). Санкт-Петербург: РХГА, $672 \mathrm{c.}$

7. Палама Г., свт. (1993). Беседы (Омилии). Ч. 1. М.: Паломник, 269 с.

8. Штейнер Р. (2009). Апокалипсис. Ереван: Лонгин, 448 с.

\section{Bibliography}

1- Voloshin M.A. (1977). Stihotvorenija. L.: Sovetskij pisatel', 464 s.

2- Damaskin I., sv. (1913). Tri zashhititel'nyh slova protiv poriajushhih svjatye ikony ili izobrazhenija // Polnoe sobranie tvorenij sv. Ioanna Damaskina. SPb., t. 1. $442 \mathrm{~s}$.

3- Dionisij Areopagit (2002). O nebesnoj ierarhii // Dionisij Areopagit. Sochinenija. Maksim Ispovednik. Tolkovanija. SPb.: Aleteja, $864 \mathrm{~s}$. 
4- Zobnin Ju.V. (2000). Strannik duha // N.S. Gumilev: pro et contra. Lichnost' $i$ tvorchestvo Nikolaja Gumileva v ocenke russkih myslitelej $i$ issledovatelej. Antologija. Sankt-Peterburg, Izd-vo RHGA, s. 6-52.

5- Maksim Ispovednik (2002). Tolkovanija // Dionisij Areopagit. Sochinenija. Maksim Ispovednik. Tolkovanija. SPb.: Aleteja, $864 \mathrm{~s}$.

6- N.S. Gumilev: pro et contra. Lichnost' i tvorchestvo Nikolaja Gumileva v ocenke russkih myslitelej i issledovatelej. Antologija. (2000). Sankt-Peterburg: RHGA, 672 s.

7- Palama G., svt. (1993). Besedy (Omilii). Ch. 1. M.: Palomnik, 269 s.

8- Shtejner R. (2009). Apokalipsis. Erevan: Longin, 448 s.

\author{
HOW TO CITE THIS ARTICLE \\ Koshemchuk, T. A., \& Bondarev, A. V. (2021). Apocalyptic \\ Images and Their Variations in N. S. Gumilyov's \\ Poetry. Issledovatel'skiy Zhurnal Russkogo Yazyka I \\ Literatury, 9(2), 53-73. \\ DOI: $10.52547 /$ iarll.18.53
}

URL: https://journaliarll.ir/index.php/iarll/article/view/207 apriptrats

(c) (7) 


\section{تصاوير آخرالزمانى و انواع آنها در آثار منظوم ذ.س.كوميليوف}

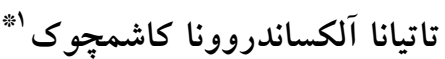

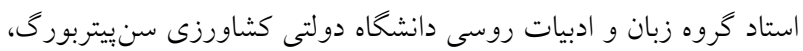

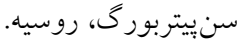

$$
\begin{aligned}
& \text { آلكسئى ولاديميروويج بوندارف }
\end{aligned}
$$

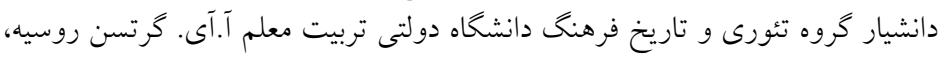

$$
\begin{aligned}
& \text { سنبيتربور ك، روسيه }
\end{aligned}
$$

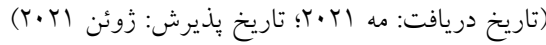

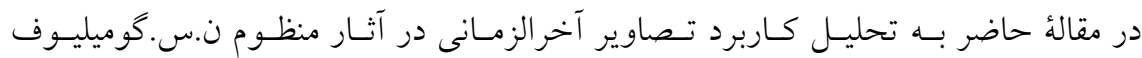

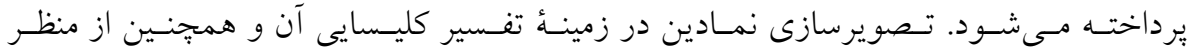

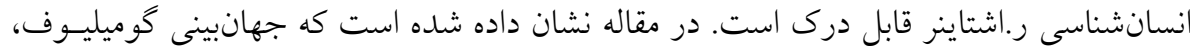

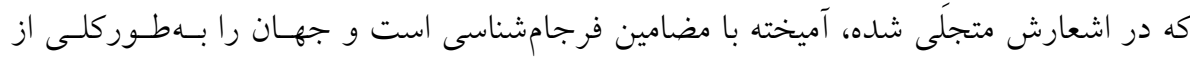

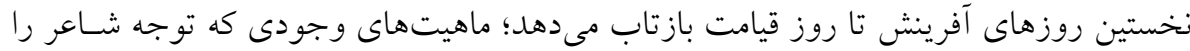

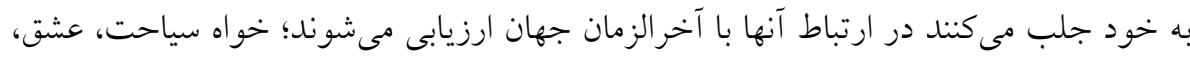

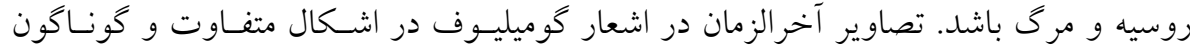

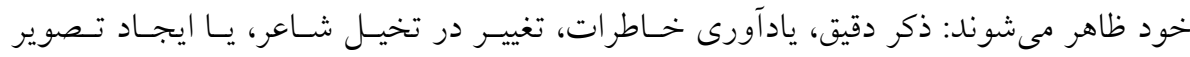

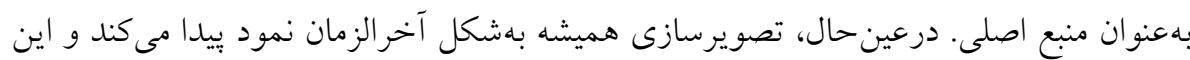

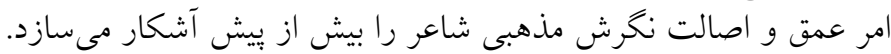

وازگًان كليدى: شعر كوميليوف، تصاوير نمادين، آخرالزمان، تفسيرهاى كليسايى، انسانشناسى

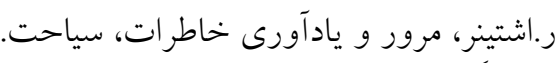

1. E-mail:koshemchukt@mail.ru * نويسنده مسئول

2. E-mail: avbondarev@mail.ru نوع مقاله: علمى- يُزوهشى هُول 